\title{
Erysipelas of the child: About 30 cases
}

\author{
Saadani CH*, Douhi Z, Baybay H, Elloudi S and Mernissi FZ \\ Department of Dermatology, CHU, Hassan II, Fes, Morocco
}

\begin{abstract}
Erysipelas is a non-necrotizing infectious dermo-hypodermitis, classically caused by Group A hemolytic Streptococcus B. It is a relatively common disease in adults and the elderly, but it is rare in children and exceptional in infant, according to data from the literature.
\end{abstract}

\section{Introduction}

A retro-prospective study was conducted in the dermatology department in collaboration with paediatric services at CHU Hassan II, Fez, covering 6 years, from March 2012, in February 2018, including all cases of erysipelas at children under 15 , and excluding adult erysipelas and necrotizing dermo-hypodermitis.

\section{Methods and materials}

The collection of clinical and interrogation data and their treatment were carried out by the software SpSS 21, including: age, sex, pathological antecedent, number of episode, gateway, headquarters, local and general signs, treatment, evolution and complications, as well as the LRINEC gravity score (Laboratory Risk Indicator for Necrotizing Fasciitis)

The purpose of our work was to conduct a descriptive study to support the clinical, therapeutic and evolutionary epidemiological profile of erysipelas in the paediatric age group, and then conducted an analytical study of qualitative variables as a function of age.

\section{Case report}

Thirty children were included in the study, with 10 infants and 20 children, with an average age of 46.66 months ( 3.88 years), and extremes ranging from 4 months to 16 years. A slight female predominance was objectified with 16 girls versus 14 boys and a sex ratio of 0.87 .

Most children had no pathological history, with the exception of 3 children, including a girl who was followed for diabetes type 1, a boy who took a self-medication of non-steroid anti-inflammatory, and a girl who had one episode of erysipelas of the face with $2^{\text {nd }}$ recurrence. The average consultation time was 3 days, and the duration of hospitalization was 4 days with extremes of 2 to 8 days. The portal of entry was found in $93.3 \%$ of cases, with 9 cases of wound and erosion, 6 cases of abrasions and 5 cases of impetigo, against only 1 case of intertrigo (Figure 1).

Erysipelas was unilateral in all cases with predominance of the lower limb in $55.2 \%$, affecting mainly the legs. The upper limb was affected in $24.1 \%$ of cases (Figure 2), and the face in $20 \%$ of cases (Figure 3).

Clinically, circumscribed inflammatory placard was found in all children, with some local signs as reported in (Figures 4 and 5). The general signs were marked by the presence of fever in $66.7 \%$. Regional

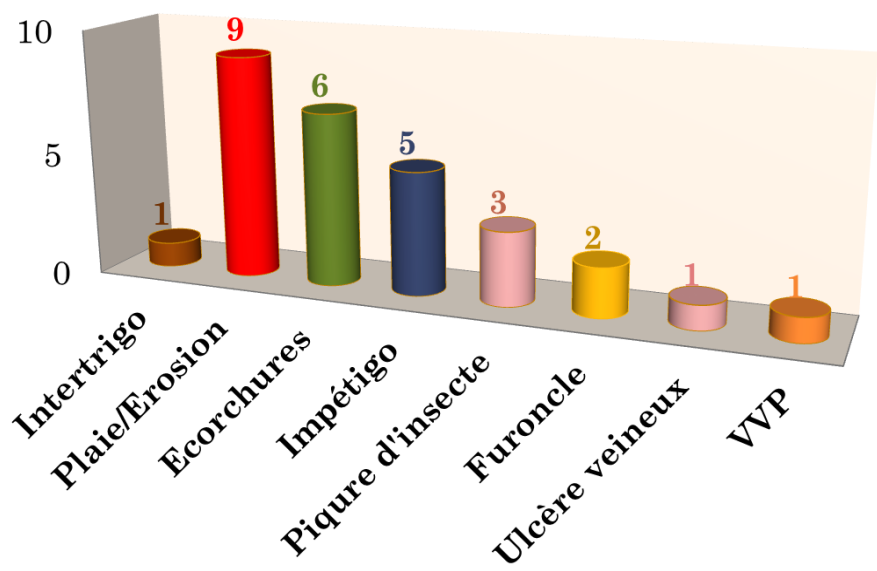

Figure 1. Diagram showing the different portal of entry

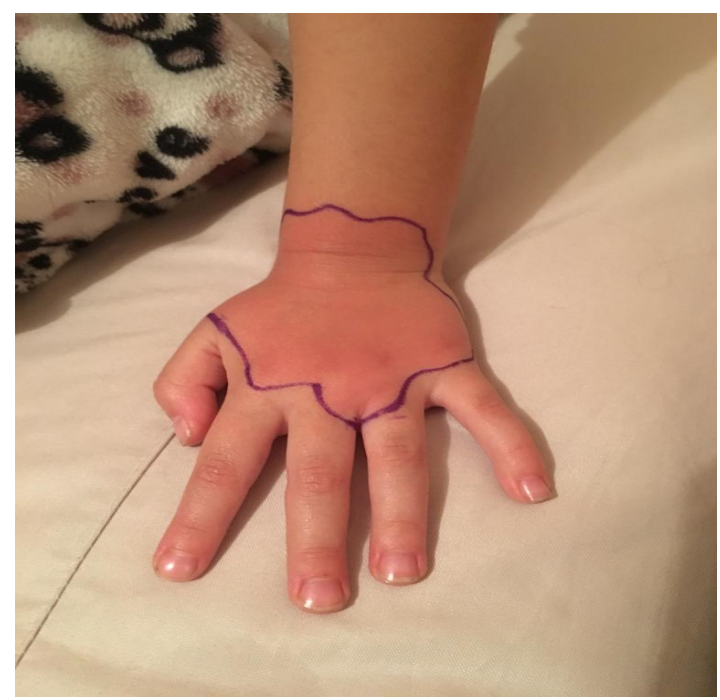

Figure 2. Erysipelas of the upper limb

${ }^{*}$ Correspondence to: $\mathrm{CH}$ Saàdani, Departement of Dermatology, CHU Hassan II, Fes, Morocco, E-mail: ch.saadani@gmail.com

Received: May 10, 2019; Accepted: May 20, 2019; Published: May 24, 2019 

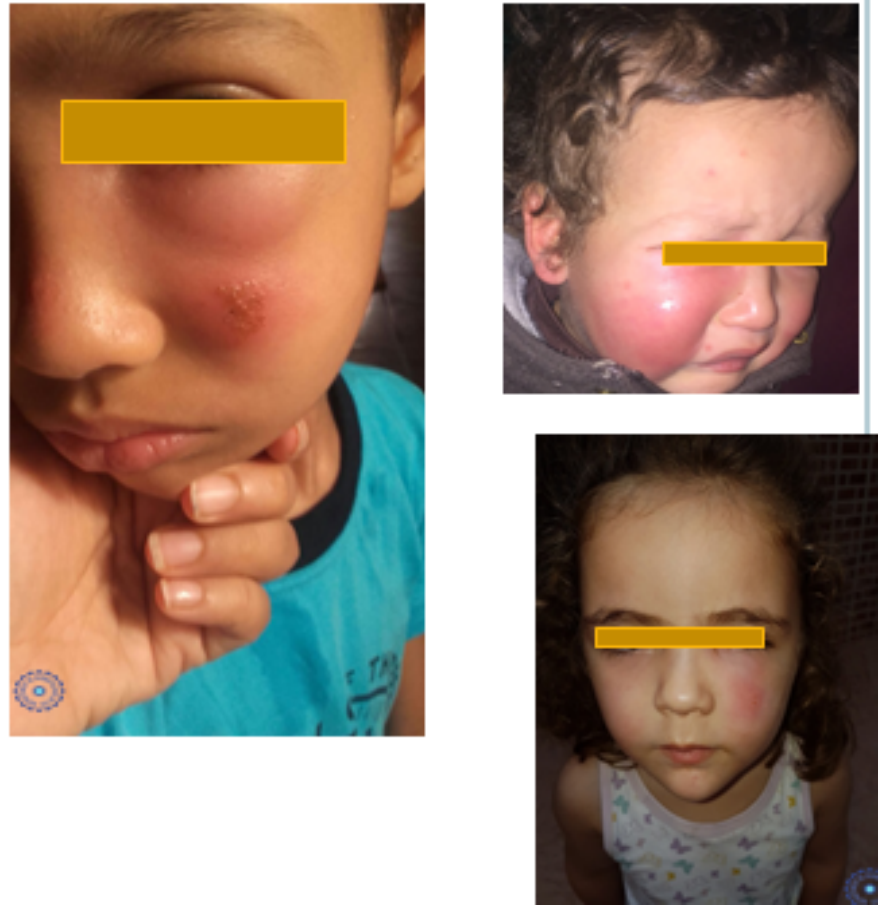

Figure 3. Erysipelas of the Face

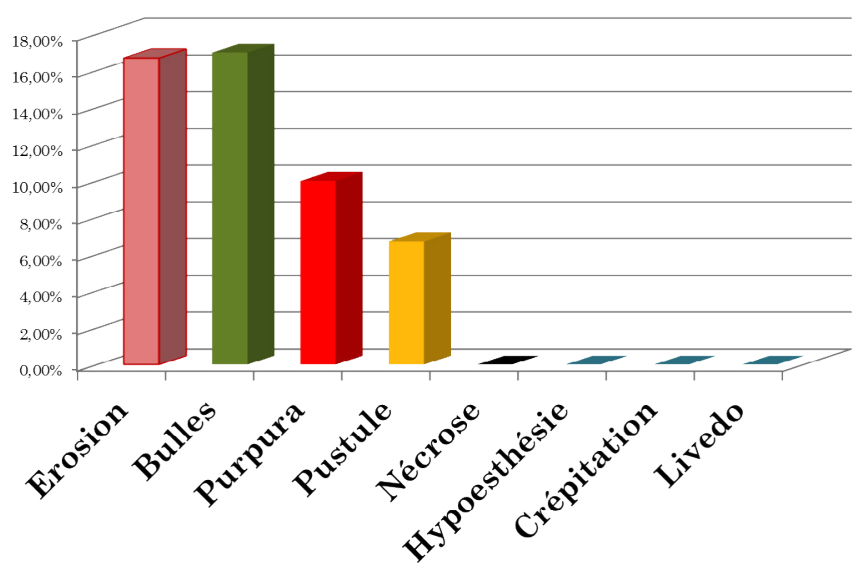

Figure 4. Diagram showing the local signs found
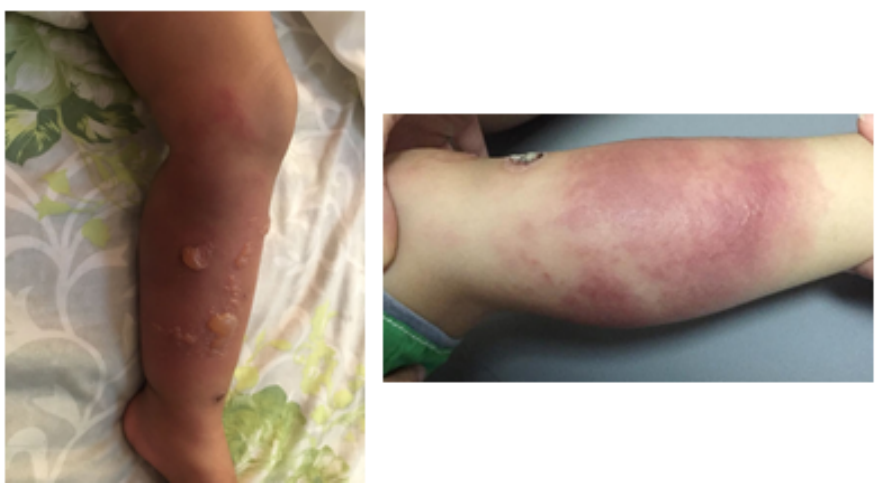

Figure 5. Presence of inflammatory plaques and bullous lesions lymphadenopathies were found in $60 \%$. The LRINEC gravity score was calculated on admission of infants, based on biological parameters (leukocytes, CRP, renal function, haemoglobin, serum alba and fasting glucose), of which one case was $>6$.

Ultrasonography of the soft parts was performed in children with local signs of infiltration or abcedation, objectifying a collection in only one case.

A standard radiograph was performed in children with the closet next to the joints, to rule out the diagnosis of osteomyelitis, normal return. All children were on amoxicillin protected at $50 \mathrm{mg} / \mathrm{kg} /$ day, and one child underwent surgical drainage of the abscess. Not to mention the treatment of the front door and adjuvant treatment to type of local care started in all children. The evolution was favourable for the 30 children with a total duration of treatment of 3 weeks. No cases of residual lymphoedema were observed

Coming to our second part, which is the analytical study where we compared the qualitative variables according to the age, including all the cases of erysipelas followed in our formation and included in our study. Indeed, there was no significant difference regarding sex, or the female predominance was in the 2 age groups. On the other hand, there was a large difference in history, with diabetes predominating, obesity and lymphoedema in adults. In addition, the consultation time and length of hospital stay were significantly shorter in children than in adults. Significant differences were also observed with respect to the type of entryway, where wounds and impetigo were prominent among children, against intertrigo inter toe, largely predominant in adults. Other differences were noted with respect to seat, local and general signs, and the significantly higher LRINEC severity score in adults than in children. Finally, lymphedema, which is the most common complication in adults in the long term, is absent in children (Table 1).

\section{Discussion}

Erysipelas is an acute cutaneous and subcutaneous infection, characterized by its rarity in children and infants [1]. In France, in children, cases are sporadic, with no obvious increase in the number of cases, unlike adults. The annual incidence is globally low, lower than 1 / 100,000 inhabitants [2]. Anglo-Saxon publications of the last ten years have shown their resurgence, with their mortality and morbidity related to toxic shock syndrome and necrotizing fasciitis [3]. In the Maghreb, Tunisian series confirm this rare nature of this infection in children [4].

Erysipelas is classically due to group A haemolytic streptococcus B. However, other germs may be the cause, especially staphylococcus, especially in the presence of a bullous impetigo as portal of entry, but the confusion is what it is a primitive aetiology, or it is a co-infection with the streptococcus is always plausible. Also, E. coli was found in cases of erysipelas of newborn or premature infants [5] and was considered to be a late fetal-fetal infection. Haemophilus influenzae once common but has since disappeared from the generalization of vaccination.

The question is, why is erysipelas, which is an infectious dermohypodermitis, interested in the child? The hypothesis suggests that in children, immunity is insufficient to obtain a satisfactory level of neutralizing antibodies against exotoxins and surface proteins [6].

The feature of erysipelas in children concerns the portal of entry, which is predominated by wounds, abrasions and impetigo, unlike in 
Table 1. Analysis of qualitative variables by age

\begin{tabular}{|c|c|c|c|}
\hline Characteristics & Childhood & Adult & $P$ Value \\
\hline $\begin{array}{l}\text { Sex } \\
\text { M } \\
\text { F } \\
\end{array}$ & $\begin{array}{l}14 \\
16\end{array}$ & $\begin{array}{l}121 \\
147\end{array}$ & 1 \\
\hline $\begin{array}{l}\text { History } \\
\text { Previous episode } \\
\text { Diabetes } \\
\text { Obesity } \\
\text { Lymphedema } \\
\text { NSAIDs/Cortico }\end{array}$ & $\begin{array}{l}1 \\
1 \\
0 \\
0 \\
1\end{array}$ & $\begin{array}{l}57 \\
75 \\
75 \\
58 \\
39\end{array}$ & $\begin{array}{c}0.19 \\
0.002 \\
0.001 \\
0.0046 \\
0.15\end{array}$ \\
\hline Consultation time & 3 & 6 & 0.04 \\
\hline Duration of hospitalisation & 4 & 9 & 0.032 \\
\hline $\begin{array}{l}\text { Porte d'entrée } \\
\text { Wound } \\
\text { Scratch } \\
\text { Impétigo } \\
\text { Mycosique intertrigo } \\
\text { Leg ulcer }\end{array}$ & $\begin{array}{l}9 \\
8 \\
5 \\
1 \\
1\end{array}$ & $\begin{array}{c}18 \\
11 \\
0 \\
134 \\
10\end{array}$ & 0.0043 \\
\hline $\begin{array}{l}\text { Siège } \\
\text { MI } \\
\text { MS } \\
\text { face }\end{array}$ & $\begin{array}{l}17 \\
7 \\
6\end{array}$ & $\begin{array}{c}202 \\
29 \\
15\end{array}$ & 0.042 \\
\hline $\begin{array}{l}\text { Local signs } \\
\text { Bullous lésions } \\
\text { Erosion } \\
\text { Purpura } \\
\text { nécrosis } \\
\end{array}$ & $\begin{array}{l}6 \\
5 \\
3 \\
0\end{array}$ & $\begin{array}{c}103 \\
112 \\
81 \\
11\end{array}$ & $\begin{array}{c}0.047 \\
0.008 \\
0.001 \\
0.61\end{array}$ \\
\hline $\begin{array}{l}\text { General signs } \\
\text { Fever } \\
\text { ADP }\end{array}$ & $\begin{array}{l}20 \\
18 \\
\end{array}$ & $\begin{array}{l}97 \\
65\end{array}$ & $\begin{array}{l}0.001 \\
0.000\end{array}$ \\
\hline LRINEC $>6$ & 1 & 60 & 0.017 \\
\hline $\begin{array}{l}\text { Complications } \\
\text { Abcess } \\
\text { Résiduel Lymphedema }\end{array}$ & $\begin{array}{l}1 \\
0\end{array}$ & $\begin{array}{l}40 \\
90\end{array}$ & $\begin{array}{l}0.095 \\
0.001\end{array}$ \\
\hline Nécessité d'ajout ATB & 0 & 45 & 0.037 \\
\hline
\end{tabular}

adults which mycotic infections are the most frequent. The beginning of the symptomatology is often brutal with very marked general signs. The classic inflammatory placard is usually found with sometimes local signs (Bubbles, purpura ....) Osteomyelitis and osteoarthritis are the main differential diagnoses of erysipelas in children, especially for the forms located next to the joints, hence the interest of completing a standard radiography to eliminate these orthopedic emergencies. Hospitalization is not always necessary, nevertheless, there are some factors of gravity leading to indicate a hospitalization in urgency [7].

- The severity of the general picture

- The nature of the local signs (bullous, purpura, limited necrosis) or the presence of a local risk (facial involvement).
- Diagnostic uncertainty: atypical clinical signs or suspicion of deeper dermo-hypodermitis

- A LRINEC score greater than 6

- Predictable compliance difficulties or the need for bed rest.

Complications are rare but can be serious, especially in infants and premature infants [8], by the installation of necrotizing fasciitis, toxic shock or sepsis

Antibiotic prophylaxis is rarely needed [9]. Indeed, in children, recurrences are less frequent, and residual lymphoedema is usually absent.

\section{Conclusion}

The erysipelas of the child is not so rare according to our study. We have reported the main clinical and progressive features of erysipelas in children compared to adults. It is an affection which remains of good prognosis.

\section{References}

1. Jait N (2015) Erysipèle chez l'enfant: diagnostic et traitement [thèse]. Rabat: université Mohamed V

2. Bernard P (1992) Dermo-hypodermal bacterial infections. Current concepts. Eur J Med 1: 97-104. [Crossref]

3. Goettsch WG, Bouwes Bavinck JN, Herings RM (2006) Burden of illness of bacterial cellulites and erysipelas of the leg in the Netherlands. J Eur Acad Dermatol Venereol 20: 834-835. [Crossref]

4. Ben abdallah chbchoub.R; Aydi.Y; Turki.F Erysipèle chez l'enfant : à propos de 22 cas pédiatriques. pédiatriques [Poster]. Sfax : Hopital Hédi Chaker

5. Gouache E, Chantier E, Hubert N, Rivière MF (2013) Dermohypodermitis and gut translocation Escherichia coli septicemia in a newborn infant. Arch Pediatr 20: 26-29. [Crossref]

6. Larru B, Gerber JS (2014) Cutaneous Bacterial Infections Caused by Staphylococcus aureus and Streptococcus pyogenes in Infants and Children. Pediatr Clin N Am 61: 457-458. [Crossref]

7. Vayalumkal JV, Jadavji T. (2006) Children Hospitalized with Skin and Soft Tissue Infections. Pediatr Drugs 8: 99-101. [Crossref]

8. Tarbé de Saint Hardouin AL, Mariani P, Esteve V, Msélati JC, Lorrot M, et al. (2015) Dermo-hypodermitis caused by group B Streptococcus in infants under 3 months of age: A retrospective study in two hospitals. Archives de Pédiatrie 22: 693-698. [Crossref]

9. Sjöblom AC, Eriksson B, Jorup-Rönström C, Karkkonen K, Lindqvist M (1993) Antibiotic prophylaxis in recurrent erysipelas. Infection 21: 390-393. [Crossref]

Copyright: (C2019 Saadani CH. This is an open-access article distributed under the terms of the Creative Commons Attribution License, which permits unrestricted use, distribution, and reproduction in any medium, provided the original author and source are credited. 